\begin{tabular}{|c|c|c|}
\hline \multirow{2}{*}{\multicolumn{2}{|c|}{$\begin{array}{ll}\text { DE } & \text { DE GRUYTER } \\
\text { OPEN }\end{array}$}} & ECONOMIC THEMES (2018) 56(1): 127-138 \\
\hline & & DOI 10.2478/ethemes-2018-0008 \\
\hline
\end{tabular}

\title{
DO SERBIAN COMPANIES PROVIDE RELEVANT DISCLOSURES ABOUT GOODWILL?
}

\section{Dejan Spasić}

\author{
University of Niš, Faculty of Economics, Republic of Serbia \\ $\triangle$ dejan.spasic@eknfak.ni.ac.rs
}

\section{UDC}

657

Original scientific paper

Received: 05.03.2018 Accepted: 27.03.2018

\begin{abstract}
IFRS 3 have been adopted to increase the relevance of information on business combinations. Consequently, it is expected that information on goodwill will contribute to that goal. By analysing the sample of the most important companies in the Republic of Serbia, this paper identifies several key areas of disclosure regarding recognition, initial recognition, and subsequent measurement of goodwill. All companies listed on the Belgrade Stock Exchange (BSE) which prepare consolidated financial statements are taken for the sample. In addition, the paper includes selected non-listed companies (that are most important for the Serbian economy according to the criteria of revenue, number of employees, and the share in the total GDP) in the sample. The final sample consists of 156 consolidated financial statements of 43 groups in the analysed four-year period (2013-2016). Descriptive statistic is used. The author found a low level of disclosure, which is further accompanied by misapplication of IFRS.
\end{abstract}

Keywords: Goodwill, IFRS, relevance, disclosures, impairment test, impairment loss, amortisation

JEL classification: M41, G32, G34

\section{Introduction}

In the modern business environment intangible assets (including goodwill) play an important role. Nevertheless, the interest to interpret the essence of goodwill and its accounting scope has existed for over a hundred years. In this regard, Brunovs and Kirsch (1991) state that Hughes, in his 1982 study, identified trade and legal guidelines regarding goodwill much earlier, in 1417. The original use of this term was associated with customer loyalty. The first interpretation of this term in literature was given by Lord Elton in one of his favourite bars in England, where he 
defined goodwill as "nothing more than the probability that the customers will resort to the old place" (Owens, 1923, p 282, quotation taken from: Qasim et al, 2013, p. 63). However, accountants and many others criticised close identification of goodwill with loyalty and place. Later, the understanding of goodwill was extended to other intangible assets that allowed generating abnormal return (Scott, 2012).

Controversial interpretation of this intangible asset arises precisely from the difficulty of identifying its components, on the one hand, and the lack of knowledge of its true value up to the moment of its market verification, and, thus, failure to fulfil one of the basic conditions for its recognition as a separate item in the balance sheet (statement of financial position), on the other hand. Nevertheless, it is generally accepted as an internally generated intangible asset, which may represent a significant success potential for a company, and which will be recognised in the financial statements only if it is market-verified.

Market verification of goodwill is only possible in a business combination, when the acquirer pays a price higher than the fair value of the acquired assets and assumed liabilities (or to take control). When adopted, IFRS 3 - Business combinations was intended to provide more relevant and reliable information on business combinations, and, hence, the acquired goodwill. However, relevant studies and reporting practice indicate that there are certain accounting areas and, hence, goodwill reporting areas, where there are certain weaknesses which, ultimately, reduce the relevance of information on this balance sheet item, as well as the financial statements as a whole.

Based on the above, the objective of the paper is to point out to some aspects of recognition, initial recognition, and subsequent measurement of goodwill in accordance with IFRS, which occur in the reporting practice of the most important Serbian companies. Accordingly, the paper is divided into five parts. After the introduction, the author briefly presents the economic essence of goodwill and its importance. The third part gives research design, the fourth part presents research findings, while the fifth part discusses the results with the concluding remarks.

\section{Interpretations of goodwill and its importance: A literature review}

Controversies regarding the accounting for M\&A transactions and, hence, goodwill accounting have occurred much later than the regulations related to the formal procedure and legal conditions for their implementation. Nevertheless, a large number of authors have dealt with the interpretation of the essence of goodwill throughout history. Depending on the research focus (accounting, marketing, law, etc.), different definitions can be encountered. "Goodwill amounts theoretically represent amounts of incremental investment paid to earn abnormal returns of investments" (Wen \& Moehrle, 2016, p.12). In other words, goodwill exists if the company earns above its average cost of capital. 
According to a certain number of authors, goodwill and its value can be estimated by comparing the market value of the company and the carrying amount of its net assets. This understanding carries the risk of uncertainty and, often, the unreliability of the determined difference in the above-mentioned determinants of goodwill, given the fluctuations in the market value of the company, which are conditioned not only by economic but also, often, by speculative reasons on the capital market. What is more, the carrying amount of net assets is often subject to underestimation or overestimation, under the influence of applied accounting policies. In addition, as with the Scott definition (2012, p. 217), goodwill is associated with all internally generated intangible assets, regardless of whether they can be identified and evaluated separately from goodwill. Finally, measuring future return as the basis for measuring this economic value is quite difficult and brings a lot of uncertainty (Qasim et al., 2013, p. 64).

Unlike previous views, International Financial Reporting Standards (IFRSs) define goodwill as assets "representing future economic benefits arising from other assets acquired in a business combination that cannot be individually identified and separately recognised" (IAS 38, paragraph 11; IFRS 3, Appendix A).

For accounting purposes, it is necessary to make a distinction between marketunverified (original) and market-verified (derivative) goodwill. Only with market verification, a particular asset, including goodwill, may be subject to recognition in financial statements. "Derivative" goodwill occurs in the acquisition transaction, through a merger or acquisition, which is why it is also called acquired goodwill. Specifically, payment (transfer of compensation) by the acquirer to take control or take over the acquired entity over the fair value of its net assets is recognised as goodwill in an amount that cannot be allocated to internally generated intangible assets of the acquired entity, and, as such, separately recognised in the financial statement of the acquirer.

"An important characteristic of goodwill is that it should be inseparable from the business: it cannot be sold without selling the business that it is associated with" (Lycklama à Nijeholt et al., 2012, p. 3). Therefore, goodwill has a significant importance not only in both financial and management reporting, but also as a resource that could be a major challenge for controlling. A particular importance in this context is the consideration of the uncertainty of future developments of this intangible asset, which a controlling instrument must adequately reflect (Kasperzak \& Wassermann, 2009, p. 120).

The importance of goodwill has changed dramatically since the introduction of new accounting standards for business combinations at the beginning of the 21st century. Scrapping of pooling method and goodwill amortization (it had been existed in previous IAS 22), and the adoption of an impairment-only approach for goodwill (in accordance with both IFRS 3 and U.S. SFAS 141 and SFAS 142), provide sufficient scope for increasing overall discretion in the company financial 
reporting on goodwill. Therefore, the disclosures about goodwill become more important in the new millennium.

This is confirmed by the research of Baboukardos and Rimmel (2014). They found that "in the case of purchased goodwill, fair value accounting generates relevant accounting numbers but only in companies that comply highly with IFRS disclosure requirements".

Having in mind the above mentioned, the author wants to examine the extent to which Serbian companies apply accounting policies regarding goodwill and whether disclosed information on goodwill is relevant.

\section{Research design}

\subsection{Defining research questions}

Recognition and measurement of goodwill in accounting terms brings a significant number of problems and challenges, since the related issues may affect the final judgment of the users of the financial statements on the relevance of information on this balance sheet item. It is, therefore, of crucial importance that investors and other users of financial statements get both quantitative and qualitative disclosures in the Notes. For the purposes of this paper, the author has identified two issues: (1) managers' tendency towards (non)-recognition of goodwill and its initial recognition; and (2) subsequent measurement of goodwill. These issues pose a challenge not only for theoreticians, but also for accountants in practice.

In the Republic of Serbia, IFRS have been applied with the preparation of consolidated financial statements since 2002, when the Law on Accounting and Auditing prescribed the obligatory application of these standards for all companies that compile consolidated financial statements. It should be noted that the 2002 law prescribed this obligation for individual financial statements of all companies, regardless of the size, and the new law of 2006 exempted small businesses from this obligation. Only with the 2013 law has the application of IFRS been limited to large entities and entities that compile consolidated financial statements, while small and medium entities apply IFRS for SMEs.

Therefore, for more than 15 years there is a practice of compiling consolidated financial statements in the Republic of Serbia in accordance with IFRS. In this paper, we want to find the answers to two research questions:

(RQ 1) Do managers recognise goodwill in consolidated financial statements and how often?

(RQ 2) Is the recognised goodwill tested for impairment and is the information about it in the Notes to consolidated financial statements sufficient and relevant for decision making? 


\subsection{Sample and Data Collection}

In order to realise the objective of this paper, in accordance with the defined research questions, the sample consists of consolidated financial statements of listed companies on the Serbian capital market (Belgrade Stock Exchange) and the selected most important unlisted companies in the Republic of Serbia.

The analysis covers the period of the last four years, i.e. 2013-2016, for which consolidated financial statements are currently available. The structure of the sample is defined as shown in Table 1:

Table 1. Sample structure and size

\begin{tabular}{|c|c|c|c|c|c|c|}
\hline \multirow[t]{2}{*}{$\begin{array}{c}\text { Basic criteria - } \\
\text { Goodwill reported or } \\
\text { not }\end{array}$} & \multirow[t]{2}{*}{$\begin{array}{c}\text { Sample } \\
\text { size }\end{array}$} & \multicolumn{3}{|c|}{$\begin{array}{c}\text { Sample from Serbian } \\
\text { capital market (by market } \\
\text { segments of the Belgrade } \\
\text { Stock Exchange) }\end{array}$} & \multirow[t]{2}{*}{$\begin{array}{c}\text { Sample } \\
\text { outside the } \\
\text { Serbian } \\
\text { capital } \\
\text { market }\end{array}$} & \multirow[t]{2}{*}{ Total } \\
\hline & & Prime & Stand. & Open & & \\
\hline \multirow{2}{*}{$\begin{array}{l}\text { Goodwill is NOT } \\
\text { recognised in } \\
\text { Consolidated Financial } \\
\text { Statements (CFS) }\end{array}$} & $\begin{array}{l}\text { Number } \\
\text { of groups }\end{array}$ & 3 & 3 & 13 & 10 & 29 \\
\hline & $\begin{array}{l}\text { Number } \\
\text { of CFS }\end{array}$ & 12 & 12 & 49 & 38 & 111 \\
\hline \multirow{2}{*}{$\begin{array}{l}\text { Goodwill is recognised } \\
\text { in Consolidated } \\
\text { Financial Statements } \\
\text { (CFS) }\end{array}$} & $\begin{array}{l}\text { Number } \\
\text { of groups }\end{array}$ & 2 & 1 & 5 & 6 & 14 \\
\hline & $\begin{array}{l}\text { Number } \\
\text { of CFS }\end{array}$ & 4 & 4 & 15 & 22 & 45 \\
\hline
\end{tabular}

Source: Author's research

All companies listed on the Belgrade Stock Exchange (BSE) are used for the sample. At the same time, unlisted companies included in the sample are the companies that are most important for the Serbian economy according to the criteria of revenue, number of employees, and the share in the total GDP. Since our research relates to consolidated financial statements in which both goodwill and non-goodwill is reported, the final sample consists of 156 consolidated financial statements in 43 groups in the analysed four-year period.It should be noted that in the analysed period some companies changed the BSE segment within which they were listed or changed their legal status (through mergers, for example). Therefore, total number of consolidated financial statements is less than the maximum expected for the analysed period.

Although the number of groups included in the sample is not large, the author considers the sample to be representative, since the Stock Exchange and the Capital Market Law impose stricter requirements on public companies regarding information disclosure and given that they are, in the nature of things, open, they are interested to provide relevant and credible information to existing and potential investors. At the same time, the selected groups outside the capital market because of their size and importance for the Serbian economy can also be a relevant sample. 


\section{Results}

\subsection{Do managers recognise goodwill in consolidated financial statements and how often? (RQ 1)}

Recognition of goodwill is one of the managers' discretionary powers, since its value can be influenced by defining the amount of payments and (much more) through the determination of the fair value of the acquired net assets of the dependent entity and the allocation of the transfer fee to the acquired net assets. Table 1 shows that as many as $67.44 \%$ of Serbian parent companies do not recognise goodwill in their consolidated financial statements. Similar findings are found in the study by Bugeja and Loyeung (2015). The above and other studies suggest that complexity of allocation of the purchase price as well as the high costs and other resources necessary in connection with this are among the reasons for the non-recognition of goodwill, which can be attributed to the results of our research. However, these reasons are not disclosed in the Notes to consolidated financial statements in our sample.

Entities that recognise goodwill in their consolidated financial statements are expected to disclose information about the nature of the business combination in which goodwill is recognised, as well as the determinants that condition its amount. Data on expected basic goodwill-related disclosures stated in the consolidated financial statements in our sample is given in Table 2.

Table 2. Disclosures of the initial recognition and initial measurement of goodwill

\begin{tabular}{|r|l|r|r|r|r||}
\hline \hline & Disclosures in Notes to Consolidated Financial & \multicolumn{2}{|c|}{ YES } & \multicolumn{2}{c||}{ NO } \\
\cline { 3 - 6 } Statements & \multicolumn{1}{|c|}{$\mathbf{n}$} & \multicolumn{1}{c|}{$\%$} & \multicolumn{1}{c|}{$\mathbf{n}$} & \multicolumn{1}{c|}{$\%$} \\
\hline 1. & Description of previous acquisitions & 14 & $31.11 \%$ & 31 & $69.89 \%$ \\
\hline 2. & $\begin{array}{l}\text { Description of acquisitions in the current reporting } \\
\text { period }\end{array}$ & 4 & $33.33 \%$ & 8 & $66.67 \%$ \\
\hline & $\begin{array}{l}\text { For acquisitions in the current reporting period } \\
\text { (only in the case of acquiring of subsidiaries in the } \\
\text { current reporting period) }\end{array}$ & & & & \\
\hline 3. & Fair value of the consideration transferred & 4 & $33.33 \%$ & 8 & $66.67 \%$ \\
\hline 4. & Fair value of acquired net assets & 3 & $25 \%$ & 9 & $75 \%$ \\
\hline
\end{tabular}

Source: Author's research

Although the least sensitive issue is the one regarding disclosure of information on how to gain control over a subsidiary, level of disclosure in a sample of Serbian companies is very low (about $30 \%$ ). It is important to point out that the recognition of internally generated intangible assets acquired in a business combination separate from goodwill in the analysed sample does not exist. The reason for this could be found in the managers' desire to avoid the obligatory amortisation of 
possibly recognised intangible assets with a finite useful life, but also in the fact that there is no good practice of Serbian companies using this option of M\&A accounting. At the same time, the European Securities and Markets Authority (ESMA) survey found that on average $76 \%$ of the analyzed business combinations recognize acquired internally generated intangible assets separately from goodwill (ESMA, 2014, par. 61).

The main determinants of goodwill or gain on a bargain purchase (the fair value of the transfer fee and the fair value of the acquired net assets) are also rarely disclosed in Serbia (33.33\%, i.e. $25 \%$ ), which is well below the European average (for example, the ESMA analysis states that in $92 \%$ of cases the fair value of the acquired assets and assumed liabilities was disclosed).

\subsection{Is the recognised goodwill tested for impairment and is the information about it in the Notes to the consolidated financial statements sufficient and relevant for decision making?( $R Q 2)$}

The results of the analysis of the disclosure of information on the subsequent measurement of goodwill on the sample of 45 consolidated financial statements in the Republic of Serbia for the analysed period are given in Table 3:

Table 3. Disclosures on the subsequent measurement of goodwill

\begin{tabular}{|c|c|c|c|c|c|}
\hline & \multirow{2}{*}{ Disclosures } & \multicolumn{2}{|c|}{ YES } & \multicolumn{2}{|c|}{ NO } \\
\hline & & $\mathbf{n}$ & $\%$ & $\mathbf{n}$ & $\%$ \\
\hline 1. & Impairment test carried out & 28 & $62.22 \%$ & 17 & $37.78 \%$ \\
\hline \multirow[t]{2}{*}{2.} & $\begin{array}{l}\text { Information on the reasons for (non)- } \\
\text { existence of impairment }\end{array}$ & 13 & $28.89 \%$ & 32 & $71.11 \%$ \\
\hline & $\begin{array}{l}\text { For the sample where the impairment test } \\
\text { was carried out }(n=28)\end{array}$ & & & & \\
\hline 3. & $\begin{array}{l}\text { Recognition of goodwill impairment losses } \\
\text { in the Profit and Loss Account }\end{array}$ & $18^{*}$ & $64.29 \%$ & 10 & $35.71 \%$ \\
\hline 4. & Description of Cash Generating Unit (CGU) & 17 & $60.71 \%$ & 11 & $39.29 \%$ \\
\hline 5. & $\begin{array}{l}\text { Method of determining the recoverable } \\
\text { amount of CGU }\end{array}$ & 13 & $46.43 \%$ & 15 & $53.57 \%$ \\
\hline 6. & Discount rate applied to DCF & 9 & $32.14 \%$ & 19 & $67.86 \%$ \\
\hline 7. & Sensitivity analysis & 6 & $21.43 \%$ & 22 & $78.57 \%$ \\
\hline
\end{tabular}

* see explanation in the text below

Source: Author's research

The fact that in almost two-thirds of the cases goodwill impairment test has been carried out shows that managers in Serbian companies in each third consolidated financial statement deprive the user of basic information on whether the test has been carried out or not (although this is an obligation under IFRS). 
However, it is still worrying that the reasons why the impairment test indicates the existence or non-existence of impairment are disclosed in almost every fourth case $(28.89 \%)$. Furthermore, probably because of the motives that will be specifically analysed in the next chapter, the recognition of impairment losses occurs in 18 of the analysed 28 cases $(64.29 \%)$. This would be more than the average that ESMA identified in its 2013 report (36\% - ESMA, 2013, par. 32). However, the data on the Serbian average should be accepted with a reserve. Specifically, in the process of data collection, it was noted that in 8 of 18 cases, the recognition of goodwill impairment loss included amounts that did not arise from the impairment test. According to the narrative explanations given in the Notes, in four cases there was a write-off (complete elimination) of goodwill due to the sale of the dependent entity; in two cases impairment was the result of new capital consolidation, although there were no new acquisitions of subsidiaries in the reporting year; in one case impairment was interpreted as a correction of errors from previous periods in accordance with IAS 8 (without explanation of which corrections, i.e. errors, with the remark by the author of this paper that more than 12 months have passed since the previous acquisition), and in one case the impairment was explained as an effect of the exclusion of a number of subsidiaries from consolidation due to the cost-inefficiency of their further consolidation. Therefore, what worries is the fact that the item that should show the actual impairment of goodwill also expresses other amounts, which in some cases are accounted for even contrary to the possibilities of accounting regulations (IFRS).

The inadequacy of testing the impairment and disclosure of information related to this is additionally confirmed by the analysis of the last four items in Table 3 . For example, disclosure about how to determine a recoverable amount of $46.43 \%$ is significantly lower than the average in Europe (92\% - ESMA, 2013, par. 38), or the discount rate used in measuring the discounted cash flow(DCF) value of cashgenerating unit (CGU) (32.14\% compared to 66\% in Europe - ESMA 2013, par. 47), and the like.

Given the extremely low level of basic disclosures related to recognition, initial recognition, and subsequent measurement of goodwill, the existence of more detailed disclosures was not further analysed (for example, description of techniques for estimating fair value, voluntary presentation of the carrying amounts of the acquired assets and assumed liabilities, individual elements in the definition of CGU, etc.). The author believes that there is sufficient basis to conclude that the relevance of the goodwill information in the analysed sample in Serbia is at a very low level.

\section{Causes and consequences of (non)-disclosure of information about goodwill- discussion and concluding remarks}

The importance of knowing the essence of goodwill, its accounting scope, and the interpretation of information disclosed in connection with this balance sheet item is 
reflected in the creation of assumptions for an adequate analysis of the achieved business performance and for the choice of the future management strategy. Specifically, the amount of recognised goodwill, as well as its subsequent measurement, can significantly affect numerous indicators, whether as traditional or as modern performance measures. This is so because the relevance of the presented information gives users, primarily investors (existing and potential), the suitable information basis for decision making.

\subsection{The relevance of the disclosure relating to recognition and initial recognition of goodwill}

The accounting method for determining goodwill as a residual value, i.e. the surplus of the paid price for acquiring another entity (or control over it) above the fair value of the acquired net assets, imposes the need to consider all factors that affect its recognition and initial recognition. In fact, Purchase Price Allocation (PPA) to identifiable assets and liabilities is, in fact, the act of determining the value of goodwill that is recognized in the financial statement of the acquirer.

Therefore, there is a danger that managers would use the PPA process for the purpose of performance management in the future through a conscious recognition of a greater amount of goodwill on the basis of impairment of the fair value of the acquired net assets (or vice versa). In other words, there is a danger that nonobjective or unjustified recognition of latent reserves (as well as hidden losses) contained in the value of the acquired assets and assumed liabilities can manipulate the amount of goodwill and future performance of the combined entity (Brähler \& Schmidt, 2014, p. 1075). This is confirmed by the research in close to 300 acquisitions, where it was identified that the managers whose earnings depend on the results achieved have the tendency to recognise a greater amount of goodwill (Shalev et al., 2013). In our analysis we have come to the opposite findings, which are confirmed by further considerations.

\subsection{The relevance of the disclosure relating to goodwill impairment}

The most significant novelty about the accounting treatment of goodwill during the last decade is related to its subsequent measurement. The abandonment of amortisation and the introduction of the impairment test led to criticism at the expense of the new model of the subsequent measurement of goodwill not only in practice, but also to great extent in academic debates. Criticisms are related to the given great discretion to managers, who, through (non)-recognition of goodwill impairment losses, manage performance in accordance with their interests. In support of this conclusion, the president of the IASB, Hans Hoogervorst, also states that "given its subjectivity, the treatment of goodwill is vulnerable to manipulation of the balance sheet and the profit and loss" (André et al., 2015, p. 484). Also, although there are opposite results, Sun (2016) confirms in his study that "overall, 
evidence suggests that managers with greater ability play an important role in preventing or reducing goodwill impairment".

Due to the significant impact on the achieved and future business performance, it is expected that the information on the impairment test presented in the Notes will be relevant and credible. However, we believe that the disclosures the author identified in the sample do not provide relevant information on the treatment of goodwill after its initial recognition.

Bearing in mind the consequences of applying the concept impairment test only, literature and practice increasingly discuss the (non)-justification of abandoning classical goodwill amortisation. It is justifiable to ask whether occasional, i.e. irregular (often at the request of the managers), goodwill write-off is in accordance with one of the basic principles of determining the periodical result, i.e. the matching principle (Protzek, 2003, p. 497). At the same time, amortisation of goodwill, on a systematic basis, in addition to providing more certain allocation of costs on that basis, contributes to the compensation of cash flows made to acquire another business. Theoretically, in extreme cases, it is possible that during the entire life of the company, until its termination, goodwill will not be written off at all, which will certainly result in a false result, since with the company liquidation it will not be cashable.

As a reminder, in accordance with IFRS for SMEs, amortisation is calculated for goodwill (maximum 10 years), with the possibility of extraordinary write-offs due to impairment. In that sense, it seems justified for us to have a similar solution when it comes to treating goodwill in entities that apply IFRS.

\section{References}

André, P., Filip, A.\& Paugam, L. (2015). The Effect of Mandatory IFRS Adoption on Conditional Conservativism in Europe. Journal of Business Finance \& Accounting, 42(3-4), 482-514.

Baboukardos, D. \& Rimmel, G. (2014). Goodwill under IFRS: Relevance and disclosures in an unfavorable environment. Accounting Forum, 38(1), 1-17.

Brähler, G.\& Schmidt, S. (2014). Hidden Reserves Under IFRS - Empirical Insight. International Review of Management and Business Research, 3(2), 1073-1086.

Brunovs, R. \& Kirsch. R.J. (1991). Goodwill Accounting in Selected Countries and the Harmonization of International Accounting Standards. ABACUS, 27(2), 135-161.

Bugeja, M.\& Loyeung, A. (2015). What drives the allocation of the purchase price to goodwill?. Journal of Contemporary Accounting\&Economics, 11(3), 245-261.

ESMA. (2013). ESMA Report. European enforcersreview of impairment of goodwill and other intangible assets in the IFRS financial statements.Retrieved from: https://www.esma.europa.eu/sites/default/files/library/2015/11/201302.pdf,Accessed on: November 19, 2017.

ESMA. (2014). ESMA Report. Review on the application of accounting requirements for business combinations in IFRS financial statements. Retrieved from: 
https://www.esma.europa.eu/sites/default/files/library/2015/11/2014-

643 esma_report on the ifrs_3.pdf, Accessed on: November 19, 2017.

IASB. International Financial Reporting Standards - IFRS 3, IAS 38. (standards in force)

Kasperzak, R. \& Wassermann, H. (2009). Goodwill-Controlling nach IAS 36 [GoodwillControlling in accordance with IAS 36]. In: Reimer, M. \& Fiege, S. (Eds.) Perspektiven des Strategischen Controllings [Perspective of Strategic Controlling], (pp. 119-136). Wiesbaden: Gabler.

Lycklama à Nijeholt, M.P., Grift, Y.K. \& Blommaert, J.M.J. (2012). Goodwill measuring value creation of acquisitions: An empirical research. (Discussion Paper Series 1221), Utrecht: Utrecht School of Economics Tjalling C. Koopmans Research Institute, Retrieved from: http://www.uu.nl/rebo/economie/discussionpapers, Accessed on: 12January, 2018.

Protzek, H. (2003). Der Impairment Only-Ansatz - Wider der Vernunft [The Impairment Only Approach - Against Reason]. KoR - Zeitschrift für internationale und kapitalmarktorientierte Rechnungslegung, 3(11), 490-495.

Qasim, A., Haddad, A.E.\& AbuGhazaleh, N.M. (2013). Goodwill Accounting in the United Kingdom: The Effect of International Financial Reporting Standards. Review of Business and Finance Studies, 4(1), 63-78.

Scott, W.R. (2012). Financial Accounting Theory. 6th Edition, Prentice Hall, Pearson Canada Inc., Toronto, Ontario

Shalev, R., Zhang, I.X.\&Zhang, Y. (2013). CEO Compensation and Fair Value Accounting: Evidence from Purchase Price Allocation. Journal of Accounting Research, 51(4), 819-854.

Sun, L. (2016). Managerial ability and goodwill impairment. Advances in Accounting, incorporating Advances in International Accounting, (32), 42-51.

Wen, H. \& Moehrle, S.R. (2016). Accounting for goodwill: An academic literature review and analysis to inform the debate. Research in Accounting Regulation, 28(1), 11-21.

\section{Appendix - List of companies included in the sample}

A. Listed companies:

A1. Prime listing of the BSE:Energoprojekt Holding, NIS, Sojaprotein

A2. Standard listing of the BSE:Jedinstvo Sevojno, Komercijalna banka,Metalac

A3. Open market on the BSE:Dijamant, Galenika, Imlek, Impol Seval, Lasta, Messer Tehnogas, Planinka, Progres, Tigar, Valjaonica Sevojno, Veterinarski zavod Subotica, Energoprijekt Entel, Energoprojekt Industrija

B. Unlisted companies (Goodwill recognized in their consolidated financial statements):

Delta Holding, Delhaize Srbija, Industrija mesa Matijević, MK Group, Verano Motors, Victoria Group 


\title{
DA LI SRPSKE KOMPANIJE PRUŽAJU RELEVANTNA OBELODANJIVANJA O GUDVILU?
}

\begin{abstract}
Apstrakt: MSFI 3 je donet kako bi se povećala relevantnost informacija o poslovnim kombinacijama. Konsekventno, očekuje se da informacije o gudvilu doprinesu tom cilju. Analizirajući uzorak najznačajnijih kompanija u Republici Srbiji, u ovom radu smo identifikovali nekoliko ključnih područja obelodanjivanja u vezi priznavanja, početnog odmeravanja i naknadnog vrednovanja gudvila. U uzorak su uzete sve kompanije koje se kotiraju na Beogradskoj berzi koje sastavljaju konsolidovane finansijske izveštaje. Pored toga, u uzorak smo uključili i izabrane kompanije koje nisu listirane (koje su veoma značajne za Srpsku ekonomiju po kriterijumu prihoda, broja zaposlenih i udela u ukupnom BDP). Ukupan uzorak se sastoji od 156 konsolidovanih finansijskih izveštaja 43 grupe za četvorogodišnji analizirani period (20132016). Korišćena je deskriptivna statistika. Ustanovili smo nizak nivo obelodanjivanja, koji je dodatno praćen i pogrešnom primenom MSFI.
\end{abstract}

Ključne reči: Goodwill, MSFI, relevantnost, obelodanjivanja, test obezvređenja, gubitak od obezvređenja, amortizacija

\section{Author's biography}

Dejan Spasić is an Associate professor at Faculty of Economics, University of Niš, Serbia. He graduated from the Faculty of Economics at the University of Niš in 1993. He earned his doctorate degree in accounting from the Faculty of Economics at the University of Belgrade in 2006. Dejan Spasić has been employed at the Faculty of Economics in Niš, Serbia since 1994. He has been also honorary professor at University of Belgrade, Faculty of Economics since 2007. His area of expertise covers scientific fields of accounting with primarily focus on financial reporting, international accounting (IFRS), sustainability reporting, M\&A. He has co-authored one text-book and over sixty articles published in journals of national and international importance and proceedings of international and national scientific meeting. Dejan Spasić is a member of the European Accounting Association. 